\title{
An insight to pilonidal sinus etiology; interdigital pilonidal sinus
}

\section{Pilonoidal sinüs etiyolojisine bir bakıș; interdijital pilonidal sinüs}

\section{Sevgi Kurt Yazar, ๑ Esra Koku Aksu*, ๑ Cem Leblebici**, ๑ Merdan Serin}

Istanbul Training and Research Hospital, Clinic of Plastic Surgery; ${ }^{*}$ Clinic of Dermatology; ${ }^{* *}$ Clinic of Pathology, Istanbul, Turkey

\begin{abstract}
A 46-year-old man who was working in leather tanning industry presented to our department with a mass and intermittent purulent discharge on his left hand for three years. Total excision was performed using transpositional flap. Histopathology was compatible with pilonidal sinus. Interdigital pilonidal sinus of the hand is a rare occupational disease. It is frequently encountered in hairdressers. Penetration of foreign hair to the interdigital web space is the cause of the disease.

Keywords: Interdigital pilonidal sinus, occupational disease, dermatological surgery

Öz

Kırk altı yaşında dericilik mesleği ile uğraşan bir erkek hasta interdijital bölgede akıntı ve kitle şikayeti ile tarafımıza başvurdu. Kitlenin total eksizyonu yapıldı. Histopatolojik incelemede kitlenin pilodidal sinüs ile uyumlu olduğu görüldü. İnterdijital pilonidal sinus, ellerde nadir görülen bir meslek hastalığıdır. Sıklıkla saç kesimi ile ilgili meslek dallarında görülür. İnterdijital alana yabancı bir kııın penetre olması ile meydana gelir.

Anahtar Kelimeler: Interdijital pilonidal sinüs, meslek hastalıkları, dermatolojik cerrahi
\end{abstract}

\section{Introduction}

Interdigital pilonidal sinus (IPS) of the hand is a rare occupational disease. Joseph and Gifford' defined barber's IPS and the pathogenesis in 1954. It is caused by repeated implantation of foreign hair to the interdigital web space ${ }^{2-5}$. It is most frequently seen in hairdressers. This is the first reported case in a patient working in leather tanning industry. IPS is a clue for the acquired origin of pilonidal sinuses. Correct diagnosis and accurate surgical therapy is important for the treatment.

\section{Case Report}

A 46-year-old male presented to our department with a mass and intermittent purulent discharge on his left hand for three years. He was working in leather tanning industry. He defined that he worked with bare hand and he was exposed to foreign hair from animal leather. He was prescribed antibiotic therapy several times without any success. On dermatological examination, there was a crusted purple papule, $0.5 \mathrm{~mm}$ in diameter on the third web space of the left hand and $1 \mathrm{~mm}$ sinus opening beneath the papule (Figure 1a, 1b).

An informed consent was obtained prior to treatment. Total excision was performed after administration of methylene blue to visualize the extent of pilonidal sinus. A random transpositional flap was designed to close the defect on his third web space. The flap was transposed to the interdigital space and the donor site was closed primarily (Figure 2. a-c).

Address for Correspondence/Yazışma Adresi: Merdan Serin MD, İstanbul Training and Research Hospital, Clinic of Plastic Surgery, İstanbul, Turkey Phone: +90 5067035515 E-mail: merdanserin@gmail.com Received/Geliş Tarihi: 19.09.2017 Accepted/Kabul Tarihi: 18.01.2018 ORCID ID: orcid.org/0000-0002-1257-0591

CCopyright 2018 by Turkish Society of Dermatology and Venereology

Turkderm-Turkish Archives of Dermatology and Venereology published by Galenos Yayınevi. 


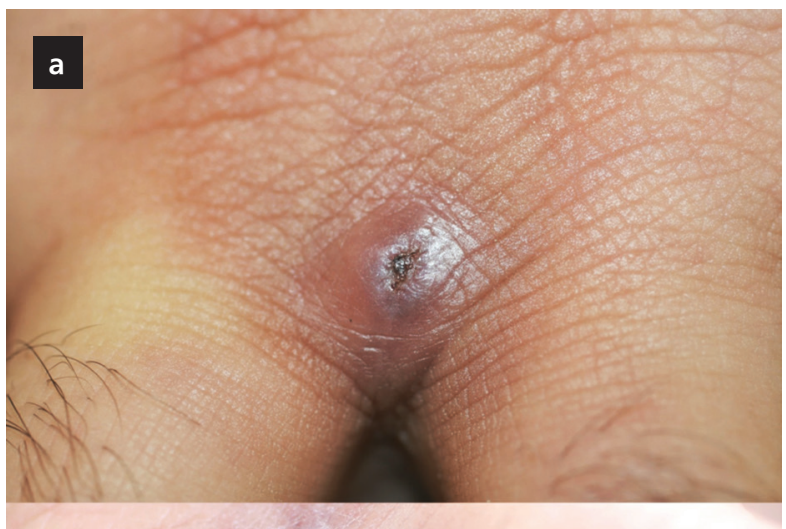

b

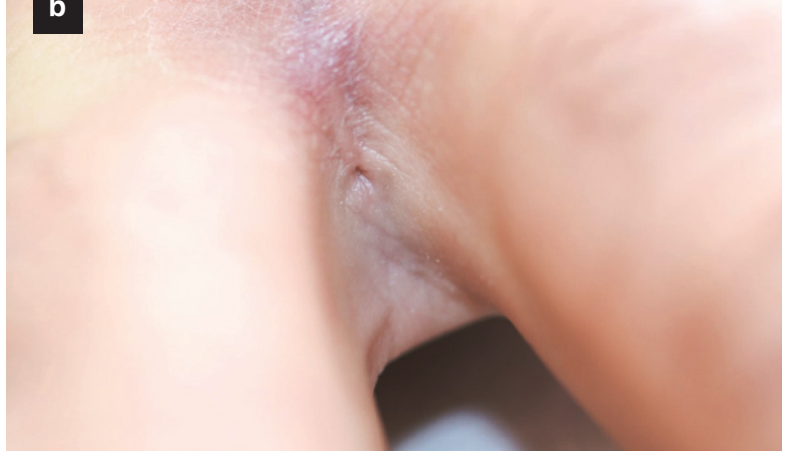

Figure 1. a) Crusted purple papule, $0.5 \mathrm{~mm}$ in diameter on the web space, b) $1 \mathrm{~mm}$ sinus opening beneath the papule

The flap healed without complications and with good cosmetic outcome. Histopathological examination revealed sinus tract opening to the surface. The sinus tract was lined with stratified squamous epithelium and hair shafts were observed in the deeper portion of the sinus (Figure $3 a, 3 b)$. There was no recurrence in one-year follow-up. Histopathology was compatible with pilonidal sinus.

\section{Discussion}

For many years, sacrococcygeal pilonidal sinus etiology could not be understood. In the $19^{\text {th }}$ century, congenital origin and developmental abnormalities were claimed. It was suggested that persistence of a caudal remnant of the neural canal was the reason for pilonidal sinus. IPS was an insight to acquired origin of pilonidal sinus. Histologically, IPS was identical with sacrococcygeal pilonidal sinus. The acquired etiology of interdigital sinus in barbers was obvious, thus, it was suggested that sacrococcygeal sinus could also be acquired. It is accepted that pilonidal sinus is caused by penetration of hair into the subcutaneous tissues. Karydakis ${ }^{6}$ defined factors in the hair insertion process of sacrococcygeal pilonidal sinus; these were 1) loose hair, 2) pressure, 3) vulnerability of the skin.

These factors are also important in the development of IPS with some differences. First, IPS occurs in non-hair bearing areas opposed to pilonidal sinus, second, IPS is a reaction to foreign body whereas pilonidal sinus contains individual's own hair, third, the root of hair penetrates ${ }^{7}$ the skin in pilonidal sinus whereas not the root but sharpened edge penetrates the skin in IPS. In IPS, penetration of cut hair leads to the formation of sinus and then cyst. Infection and discharge are among the frequent complaints. Pilonidal sinus is frequent, although interdigital
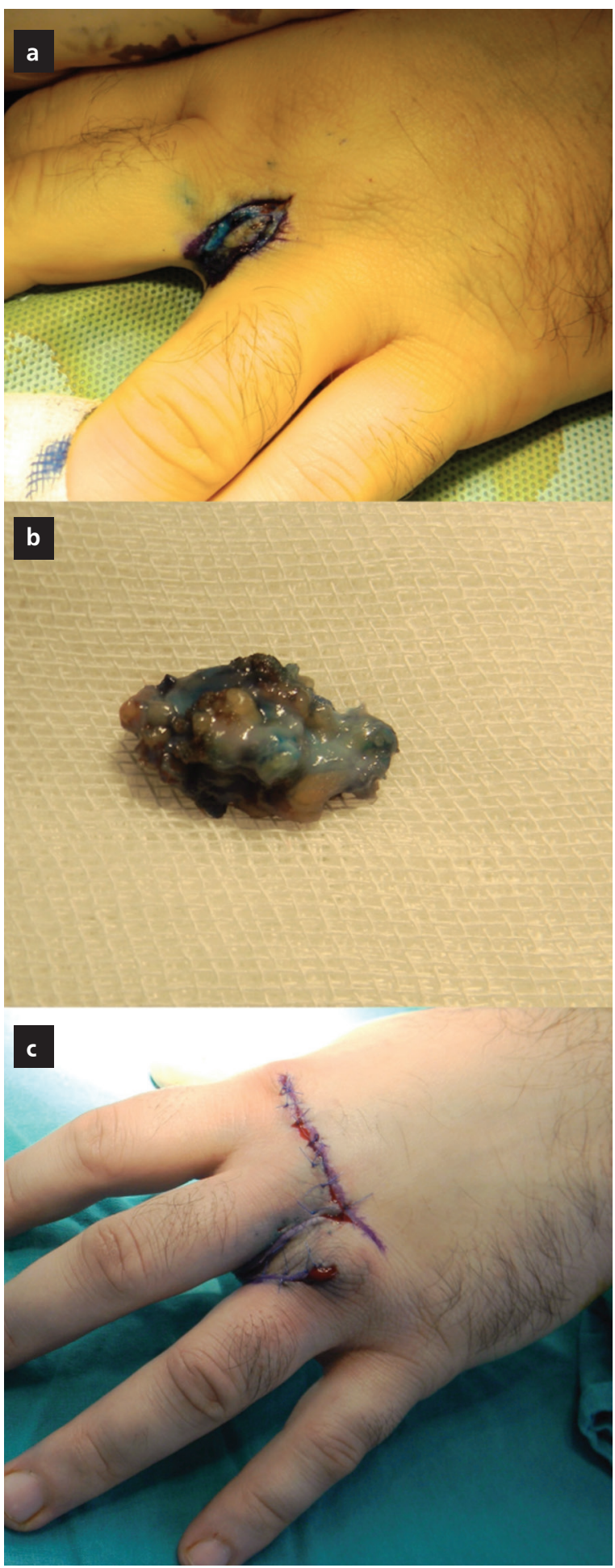

Figure 2. a) A total excision was performed after administration of methylene blue to visualize the extent of pilonidal sinus. b) Excised specimen, c) a random transpositional flap was designed to close the defect on his third web space. The flap was transposed to the interdigital space and the donor site was closed primarily

localization is very rare. It is mainly reported in hairdressers, although two cases were reported in dog groomers ${ }^{8-11}$.

The main treatment of choice is surgery ${ }^{12}$. Closure in secondary cases or in cases where an extensive resection has to be done can be challenging. 


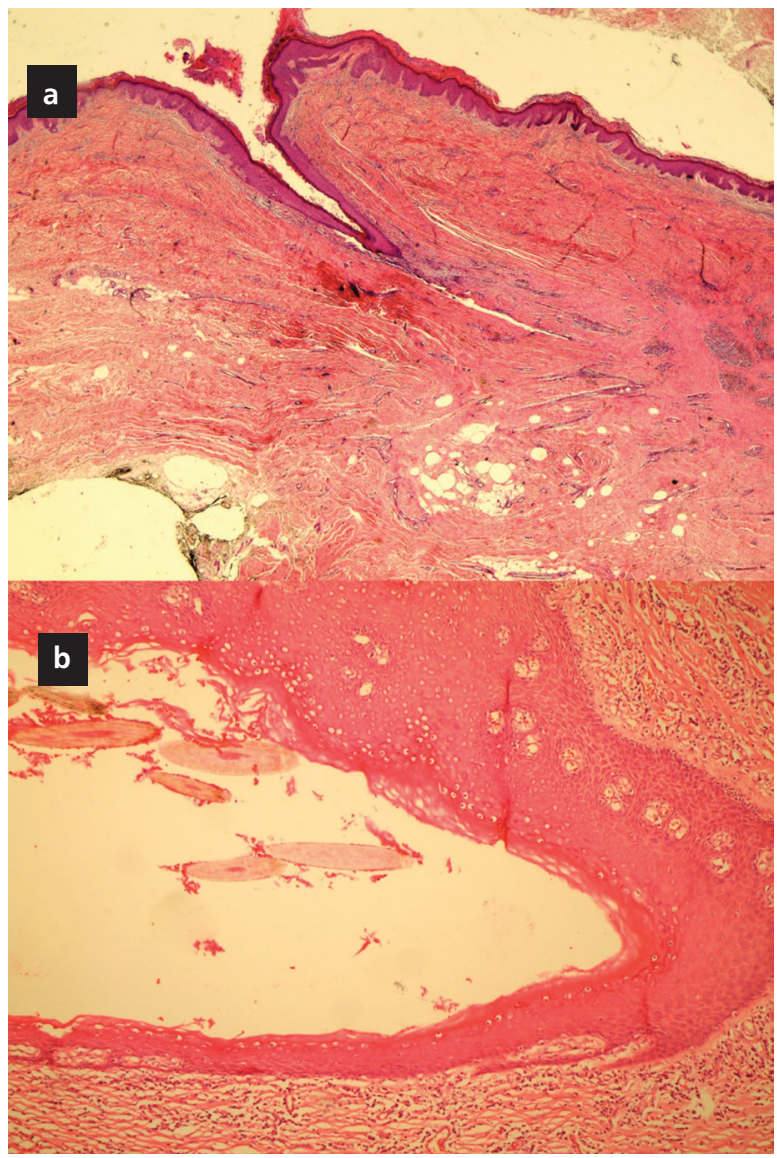

Figure 3. a) Sinus tract opening to the surface lined with stratified squamous epithelium accompanied with lymphocytic cell proliferation and fibrosis. (hematoxylin and eosin X40). b) Hair shafts inside the sinus were observed (hematoxylin and eosin X200)

In such cases, skin flaps can be required to close the defects and to obtain better healing. Transpositional flap, as performed in our patient, can be a good choice. It is simple and safe and it provides potent skin coverage which can possibly avoid penetration of hair into web space with minimal donor site morbidity. As far as we know, this is the first reported case in a patient working in leather tanning industry. IPS is a clue for the acquired origin of pilonidal sinuses. Correct diagnosis and accurate surgical therapy is important for the treatment. In addition, application of preventive measures as wearing gloves or good personal hygiene is crucial for avoiding recurrences.

\section{Ethics}

Informed Consent: Informed consent was taken.

Peer-review: Externally peer-reviewed.

\section{Authorship Contributions}

Surgical and Medical Practices: S.K.Y., Concept: S.K.Y., Design: E.K.A., Data Collection or Processing: C.L., Analysis or Interpretation: E.K.A., Literature Search: M.S., Writing: M.S.

Conflict of Interest: No conflict of interest was declared by the authors.

Financial Disclosure: The authors declared that this study received no financial support.

\section{References}

1. Joseph HL, Gifford H: Barber's interdigital pilonidal sinus: the incidence, pathology, and pathogenesis. AMA Arch Derm Syphilol 1954;70:616-24.

2. Eryilmaz R, Okan I, Ozkan OV, Somay A, Ensari CÖ, Sahin M: Interdigital pilonidal sinus: a case report and literature review. Dermatol Surg 2012;38:1400-3

3. Adams $\mathrm{Cl}$, Petrie PW, Hooper G: Interdigital pilonidal sinus in the hand. J Hand Surg Br 2001;26:53-5.

4. Yalcin D, Tekin B, Sacak B, Ayranci G, Erbarut I: Interdigital pilonidal sinus of report of two cases. Int J Trichology 2016;8:38-9.

5. Uysal AC, Orbay H, Uraloglu M, Sensoz O, Hyakusoku H: Rare occupational disease of hair dressers interdigital pilonidal sinus. J Nippon Med Sch 2007;74:364-6.

6. Karydakis GE: Easy and successful treatment of pilonidal sinus after explanation of its causative process. Aust N Z J Surg 1992;62:385-9.

7. Sondenaa K, Pollard ML: Histology of chronic pilonidal sinus. APMIS 1995; 103:267-72.

8. Efthimiadis C, Kosmidis C, Anthimidis G, Grigoriou M, Levva S, Fachantidis P: Barber's hair sinus in a female hairdresser: uncommon manifestation of an occupational disease: a case report. Cases J 2008;1:214.

9. Ballas K, Psarras K, Rafailidis S, Konstantinidis H, Sakadamis A: Interdigital pilonidal sinus in a hairdresser. J Hand Surg Br 2006;31:290-1.

10. Ito A, Yoshida Y, Yamamoto O: Case of interdigital pilonidal sinus in a dog groomer. J Dermatol 2013;40:1051-2.

11. Papa CA, Ramsey ML, Tyler WB: Interdigital pilonidal sinus in a dog groomer. J Am Acad Dermatol 2002;47(5 Suppl):281-2.

12. Aydin HU, Mengi AS: Recurrent interdigital pilonidal sinus treated with dorsal metacarpal artery perforator flap. J Plast Reconstr Aesthet Surg 2010;63:832-4. 